\title{
Implementation of President Grants for Micro Business Productive (BPUM) to Increase Productivity of MSMEs Amid Adaptation of New Normal: A Research Proposal
}

\author{
Master of Law, Djuanda University, Indonesia. \\ "Corresponding author. E-mail: yana.priyana@unida.ac.id
}

Yana Priyana

\begin{abstract}
This study aims to analyze the research on presidential assistance in increasing the productivity of MSMEs and analyze the effect of the beneficiaries of presidential aid assistance. This analysis uses a normative juridical approach using a literature study. Data collection was carried out qualitatively, describing it in words to become a sentence that can be understood, expanded, and accounted for. The deductive method, namely drawing conclusions or reasoning processes from general statements to reach certain logical conclusions, is used for data obtained from library searches. At the same time, the inductive method is used for data obtained from the field as a compliment. BPUM socialization is carried out by the Office of Cooperatives and Micro Enterprises by disseminating information by letter to all sub-districts and disseminating public information, namely through the Office of Cooperatives and Micro Enterprises website. After disseminating information, a coordination meeting was held with all sub-districts regarding the implementation of BPUM. Furthermore, the BPUM implementation mechanism begins with data submission, data cleaning, disbursement of funds, and monitoring/reporting. The effect of the implementation of BPUM in general, the beneficiaries feel that the impact of BPUM on their economy is quite good, BPUM is considered helpful for the resilience of MSMEs in times of crisis.
\end{abstract}

Keywords: BPUM, Productivity, Effect of The Beneficiaries MSMEs.

\section{INTRODUCTION}

Micro, Small, and Medium-Sized Enterprises (MSMEs) are one of the driving forces of the Indonesian economy and are critical to a country's economic and industrial progress [1]. MSMEs become the economic activity of the majority of a community, which helps a country's economy thrive. MSMEs are resilient enterprises that can thrive in any environment, such as under President Susilo Bambang Yudhoyono's administration, which endured a worldwide crisis and is currently afflicted by the Corona Virus Disease 2019 (COVID-19) Pandemic. Even if they continue to exist, many have encountered difficulties operating or maintaining their businesses.

Capital deficiency is a hindrance because capital is diverted to other uses. Government aid is required during this epidemic, particularly for Micro, Small, and Medium-Sized Enterprises (MSMEs) that are impacted, resulting in a loss of income. As a result, MSME entrepreneurs anticipate that there will be a solution to this challenge.

Regulation No. 6 of 2020 of the Minister of Cooperatives, Small and Medium Enterprises on the distribution of government assistance to microenterprises to aid in national economic recovery in the face of threats to the national economy and to save the national economy during the Covid-19 pandemic [2]. Government support is sought by the community, particularly microenterprises, to raise their money for company development or maintenance, allowing them to continue operating throughout the epidemic currently ravaging Indonesia. Economic situations deteriorated during the pandemic. According to Fathoni, the greater the threat posed by Covid-19, the more significant the decline in income. On the other hand, the smaller the threat of Covid-19, the lower the income of MSMEs [3]. With incomes declining, government help is critical for small and micro-businesses to survive the pandemic. 
In 2020, a President grants for Productive Micro Enterprises (BPUM) will be established to increase the productivity of MSME entrepreneurs while adapting to new habits. BPUM is distributed once in the amount of Rp. 2,400,000.00 (two million and four hundred rupiah), as stipulated in Article 3 of the Minister of Cooperatives, Small and Medium Enterprises' Regulation No. 6 of 2020. (1). On August 24, 2020, this productive President grants was provided to MSME actors. BPUM is one of the government's motivations for small business actors in the community.

According to the Guidelines for the Implementation of Assistance to Micro Business Actors No. 98 of 2020, BPUM is provided to micro-business actors to assist them in operating a business during a crisis caused by the Covid-19 pandemic. This assistance is provided through the National Economic Recovery (PEN) program [4]. Microbusiness players have challenges operating their firms during the pandemic, resulting in business cash purchasing daily meals. With the government program, specifically, help for micro-enterprises, it is envisaged that their businesses will survive while changing to new habits during the Covid-19 pandemic.

The government reopened BPUM with the Minister of Cooperatives and Small and Medium Enterprises of the Republic of Indonesia's Regulation No. 2 of 2021 to increase the country's economic growth. To confront the national economy's dangers and save it during the Corona Virus Disease 2019 (COVID-19) pandemic [5]. Article 1 paragraph (3) is revised to read as follows: "BPUM is distributed in the form of cash in the amount of Rp. $1,200,000.00$ (one million two hundred thousand rupiah) to micro-business actors that meet particular conditions."

The main requirements for micro-business actors to obtain BPUM are as follows: a. be an Indonesian citizen; b. have a resident registration number; c. own a microenterprise as evidenced by a letter of proposal for a candidate for a BPUM recipient from the BPUM proposer along with its attachments, and d. not be a State Civil Apparatus. These requirements are meant to facilitate a corporate entity's legal status. According to Article 1 paragraph (10 of Government Regulation No. 7 of 2021, Business Licensing is the legal authority granted to Business Actors to start and operate their businesses and activities [6].

The ease with which BPUM can be obtained has resulted in many applicants submitting applications. Even those who do not own a business can apply if they meet specific criteria. The community was enticed since this help is in the form of operating money, not a debt. Thus, the beneficiary is not responsible for refunding monies provided to unaided business players.

Given the simplicity with which this help can be applied, and the fact that it is not in the form of a debt, the community assumes that this support is supplied for free. As a result, the program funded by financial aid will fall short of the government's aim, as there are several possibilities for the general public to apply.
The researchers chose the title of this study based on the description of the research's backdrop above: Implementation of the Productive President grants for Micro Enterprises (BPUM) to Increase MSME Productivity During the Adoption of New Habits.

\section{LITERATURE REVIEW}

Our research aims to analyze the implementation (BPUM) To Increase Productivity of MSMEs Amid Adaptation of New Normal. Second, analyze the effect of President grants' implementation on Productive Micro Enterprises.

Eddy Satriya, Deputy for Micro Enterprises at the Ministry of Cooperatives and SMEs, indicated that reducing the value of the MSME BLT support grants by up to $50 \%$ was inextricably linked to the rejecting policy that restricted budget allocations. The Covid-19 Handling Committee and National Economic Recovery Committee's joint meeting (KPC PEN) decided. All money withheld boosts the health sector through the PEN initiative [7]. BPUM socialization is carried out by the Office of Cooperatives and Micro Enterprises through letter distribution to all sub-districts and public information dissemination through the Office of Cooperatives and Micro Enterprises website. Following information dissemination, a coordination conference with all sub-districts addressing the implementation of BPUM was conducted. Additionally, the BPUM implementation method begins with data collection, data cleansing, funding disbursement, and monitoring or reporting. Specifically, 1). The community initiates the proposal for BPUM data. 2). Data cleansing is the process of cleaning data from NIK examinations that get bankbacked business capital loans. 3). The payout of BPUM 2020 funding begins with notification to the public who have registered as BPUM receivers by SMS or via the BRI e-form website. 4). The Financial and Development Supervisory Agency (BPKP) supervises in partnership with and with the Cooperatives and Micro Business Office [8].

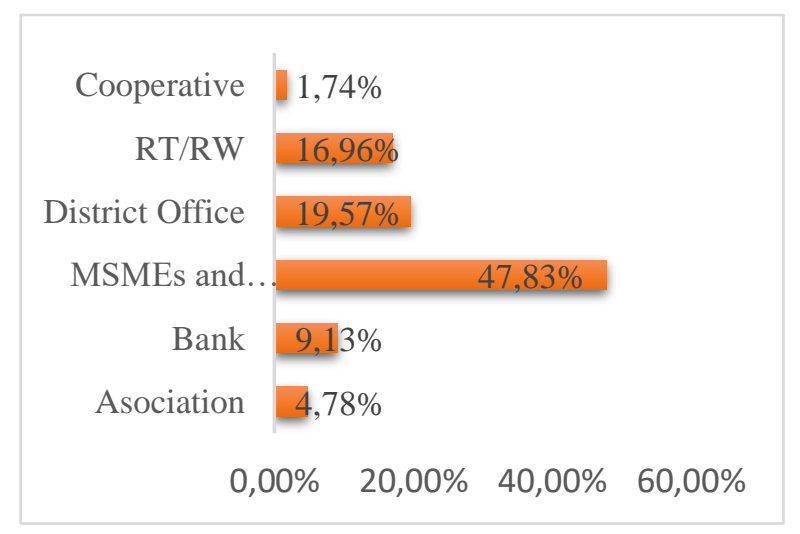

Figure 1. The place to register to get BPUM in West Java 
To the hamlet. It is possible to identify where the person enrolled for assistance. The Cooperatives and UMKM Service are the most often used channels for applicants seeking assistance with registration. The second most frequently used location is the kelurahan/desa, as it is easily accessible to the community, and the third is with the head of the RT/RW, as the RT/RW assists in collecting application forms be distributed. As a result, it can be observed that the Ministry of Cooperatives and SMEs, as the lead agency, has performed admirably in its execution, functioning as a booster for other institutions in the area, such as the outskirts or villages.

Table 1. BPUM Economic Impact Index

\begin{tabular}{|c|l|c|c|}
\hline Question & Desscription & Composite & Index \\
& & & \\
\hline Q1 & Survival & 4.94 & 0.79 \\
\hline Q2 & Employees & 4.54 & 0.71 \\
\hline Q3 & Sales & 5.07 & 0.81 \\
\hline Q4 & New & 2.73 & 0.35 \\
\hline Q5 & Emergency & 3.92 & 0.58 \\
\hline
\end{tabular}

The effect of introducing BPUM is seen in Table 1. By and large, recipients believe that BPUM has positively affected their economy (impact). The table above makes use of the Likert scale. As can be seen, the average index of 0.65 is within the $0.60-0.80$ range. This demonstrates that BPUM is regarded as beneficial to the resilience of MSMEs during times of crisis [9].

Theory of the rule of law as a grand theory. The rule of law guarantees equality for everyone before the law "Equality Before The Law" [10]. In line with this provision, every individual is equal before the law regardless of race, ethnicity, religion, and profession. The idea of the rule of law is built by developing the legal apparatus itself as a functional infrastructure of political, economic, and social institutions [11]. In line with this theory that the state can stand intact because of legal instruments that regulate all aspects of state life, the law must adapt to the current situation so that the development of law must continue to be carried out to achieve justice.

In its development, the classical rule of law model, which instituted absolute power, was met with opposition from groups who fought for a constitutional system, namely a system of government based on the constitution [12]. Constitutional democracy is a state administrator with legal politics to achieve a state goal based on constitutional law. The government cannot make regulations according to the king's will, and all rules must be based on constitutional law, which has the highest position over a law, meaning that this law is in charge of other rules. In the concept of a democratic rule of law, democracy is regulated and limited, while the law itself is determined through democratic means based on the constitution [13].
The rule of law is a form of denial of the existence of a state that embodies individual interests [14]. The rule of law prioritizes the community's interests because, essentially, the state was founded by people who wish to achieve a goal to create a state based on a law to balance a social life.

Development Law Theory as Middle Theory. The theory of development law and its elaboration at the beginning, which was around 1969, was not intended by the initiators as a theory but a concept of legal development which was modified and adapted from Roscoe Pound's Theory "Law as a tool of social engineering" which developed in the United States. In subsequent developments, the concept of development law was given the name Development Law Theory more often referred to as the UNPAD School [15].

The principle of sustainability as Applied Theory. In the Law of the Republic of Indonesia No. 20 of 2008 concerning Micro, Small, and Medium Enterprises [16], the principle of sustainability is the principle that in a planned manner strives for the development process to run through the empowerment of Micro, Small, and Medium Enterprises which is carried out on an ongoing basis to form a stable and independent economy.

\section{RESEARCH METHODS}

\subsection{Research Approach}

The normative juridical approach, namely the law, is conceptualized as a norm, rule, principle, or dogma. The normative juridical research stage uses a literature study "review of the literature" [17]. In this study, library materials are the primary data of researchers classified as secondary data, namely by examining legal material data in the form of the implementation of the Productive President grants for Micro Enterprises to increase productivity in the midst of adopting new habits.

\subsection{Data Collection Techniques}

\section{a. Document or Library Studies}

In normative legal research, document studies are the primary data collection technique because the proof of the basic assumptions (hypotheses) of the research is based on positive legal norms, legal doctrines or teachings, academic research results, and decisions made, which are all based on written documents [18].

b. Field Research (Field Research)

Field research is needed to obtain data and complement and support library research. To obtain field data, by conducting interviews using a list of questions (questionnaires) with selected respondents who are considered masters of the problem to be studied. In this way, the data collection results will obtain primary data in the form of the President grants 
for Productive Micro Enterprises to increase productivity amidst the adaptation of new habits.

\subsection{Data Collection Tool}

Data collection was carried out qualitatively, describing it in words to become a sentence that can be understood, expanded, and accounted for. Data in the field can be in the form of numbers and tables. It can happen, and data processing becomes quantitative

\subsection{Research Phase and Research Materials}

Discussions in the legal field are based on several legal materials, namely:

1) Primary legal materials consist of basic norms or rules, namely the 1945 Constitution, Law of the Republic of Indonesia Number 20 of 2008 concerning Micro, Small, and Medium Enterprises.

2) Secondary legal materials provide explanations on primary legal materials, for example, Draft Laws, Scientific Work, results of legal research, and so on.

3) Tertiary legal materials provide explanations for primary and secondary legal materials. For example: are dictionaries, encyclopedias, cumulative indexes, and so on.

\subsection{Data analysis}

Data analysis is collected qualitatively in normative legal research, describing descriptive analysis and perspectives. The analysis is formulated to collect data systematically and consistently linked to find the connection. The deductive method, namely drawing conclusions or reasoning processes from general statements to reach certain logical conclusions, is used for data obtained from library searches. At the same time, the inductive method is used for data obtained from the field as a compliment. The research results can be seen with complete and accurate data using the deductive and inductive methods.

\section{CONCLUSION}

Implementation of BPUM at the beginning with the dissemination of information through circulars, after the dissemination of information, carried out the coordination of the implementation of BPUM. Implementing BPUM begins with proposing data, initiating data, developing funds, and monitoring/reporting. Based on previous studies, the effect of the implementation of BPUM in general, the beneficiaries feel that the impact of BPUM on their economy is quite good, BPUM is considered helpful for the resilience of MSMEs in times of crisis. However, this research will make sure how the implementation is.

\section{REFERENCES}

[1] Purba, D.S. dkk. Manajemen Usaha Mikro, Kecil dan Menengah. Medan. Yayasan kita Menulis. Februari 2021.

[2] Peraturan Menteri Koperasi, Usaha kecil dan Menengah Republik Indonesia Nomor 6 Tahun 2020.

[3] Fathoni, A. Dampak Covid-19 dan Kebijakan PSBB Pemerintah Terhadap UMKM di Wuyung Surabaya. Dinar: Jurnal Prodi Ekonomi Syari'ah. Volume 3 Nomor 1. September 2019.

[4] Petunjuk Pelaksanaan Bantuan Bagi Pelaku Usaha Mikro (BPUM) Nomor 98 tahun 2020.

[5] Peraturan Menteri Koperasi dan Usaha Kecil dan Menengah Republik Indonesia Nomor 2 Tahun 2021.

[6] Peraturan Pemerintah Republik Indonesia Nomor 7 Tahun 2021.

[7] Ini Alasan BLT UMKM Dipangkas 50 Persen Menjadi Hanya Rp1,2 Juta Tahun ini, https://www.merdeka.com/uang/ini-alasan-bltumkm-dipangkas-50-persen-menjadi-hanya-rp12-juta-tahun-ini.html. 5/5/2021. Diakses pada tanggal 12 Desember 2021.

[8] Syafifah, E. Efektivitas Penyaluran Dana President grants Produktif Usaha Mikro (BPUM) Untuk Modal Kerja Dalam Meningkatkan Kesejahteraan Pelaku Umkm (Studi Kasus Pada Pelaku UMKM Di Desa Melayu). Diploma thesis. 2021, Universitas Islam Kalimantan MAB.

[9] Laporan Kajian Efektivitas Program Pemulihan Ekonomi Nasional (PEN) Provinsi Jawa Barat.

[10] Roestamy, M. et al. Asas Keadilan Dalam Suplai Makan Tahanan Kepolisian dan Lembaga Pemasyarakatan Dihubungkan Dengan Undangundang Nomor 36 Tahun 2009, Jurnal Ilmiah Living Law, Volume 12 Nomor 1, Januari 2020.

[11] Suharno. Mengadili Kebijakan: Perspektif Demokrasi dan Negara Hukum. Surakarta. Indotama Solo. Mei 2020.

[12] Adnan, I.M. Negara Hukum dan Demokrasi, Edisi Revisi. Bantul. Trussmedia Grafika. Januari 2019.

[13] Maskur, M.A. dkk. Revitalisasi Ideologi Pancasila dalam Aras Global Perspektif Negara Hukum. Semarang. Fakultas Hukum Universitas Negeri Semarang. November 2017.

[14] Junaidi, M. Ilmu Negara: Sebuah Konstruksi Ideal Negara Hukum. Malang. Setara Press. April, 2016.

[15] Tjukup, M. Penerapan Teori Hukum Pembangunan dalam Mewujudkan Peradilan 
Sederhana, Cepat dan Biaya Murah. ADHAPER: Jurnal Hukum Acara Perdata. Vol 1, No 1 (2015).

[16] Undang-Undang Republik Indonesia Nomor 20 Tahun 2008 tentang Usaha Mikro, Kecil, Dan Menengah.

[17] Reoestamy, M et al. Metode, Penelitian, Laporan dan Penulisan Karya Ilmiah Hukum pada Fakultas
Hukum. Bogor. Fakultas Hukum Universitas Djuanda. Januari 2020. Hlm 42.

[18] Bachtiar. Mendesain Penelitian Hukum. Yogyakarta. Grup Penerbitan CV. Budi Utama. September 2021. 